\title{
Hybrid UASB Reactor: A Research Evaluation for Treatment of Pharmaceutical Industry Wastewater
}

\author{
Ritvij D. Trivedi, Dipak S. Vyas* and Sejal M. Patel*
}

Civil Department, HJD Institute of Technical Education and Research, Kutch, Gujarat, India

*Corresponding author

\section{A B S T R A C T}

Keywords

Pharmaceutical wastewater; Hybrid UASB

Article Info

Accepted:

12 March 2019

Available Online:

10 April 2019
India has tremendous improvement in pharmaceutical industry. The heaps of MNCs are there, and the Vapi is one the pharmaceutical centre point of Gujarat. Anaerobic innovation is a development and it has lots of advantages. Here the reactor was structure of $1210 \mathrm{~mm}$ tall, $152.4 \mathrm{~mm}$ distance across and shining framework for bay. The 5 inspecting point are put with $180 \mathrm{~mm}$ stature contrast the tallness of bay tank is $1500 \mathrm{~mm}$. At the highest point of reactor there is a gas valve and Sludge channel at the base. Here likewise microbial examination was finished utilizing anaerobic container and gram Staining. With the fruitful start-up utilizing the Pharmaceutical's wastewater, the outcome is taken in COD, BOD, TSS, VSS, and alkalinity. The COD was greatest $71 \%$ and in the scope of $6 \%$ to $71 \%$ and BOD is additionally as same TSS and VSS are in the scope of 300 to 12000 it is increment because of microbial movement. The response is acidic in this way, that the $\mathrm{pH}$ is diminishing and alkalinity is diminishing these are in the scope of 7.9 to 6.8 and 35000 to $1000 \mathrm{mg} / \mathrm{L}$. So it very well may be reasoned that the reactor has effectiveness of $70 \%$.

\section{Introduction}

Drugs and Pharmaceutical manufacturing industry plays a key-role to the Society as a whole. The foundation of Modern Indian Drugs and Pharmaceutical Industry in the country was laid in the beginning of this century. Pharmaceutical products refer to a group of chemicals used for diagnosis, treatment, or prevention of diseases and/or health conditions. Pharmaceutical manufacturing industries generally employ batch operations for manufacture of most basic drugs and their derivatives are Formulation, Extraction and Fermentation.
Regular pharmaceutical measurement shapes are: Aerosols, cases, creams, emulsions, gels, inserts, inward breaths, infusions, water systems, salves, glues, powders, arrangements, suspensions, tablets. Around $70 \%$ of the medications devoured are strong oral dose structure (tablets and containers).

\section{Pharma wastewater: Generation and standards}

\section{The UASB technology}

The Upflow Anaerobic Sludge Blanket (UASB) reactor is the most imperative 
anaerobic treatment innovation which was created in the late 1970s in The Netherlands by Lettinga and his associates. The cross breed Upflow anaerobic ooze cover (HUASB) reactor is another idea which is the hybridized adaptation of a UASB reactor with an arbitrary pressing average help media at the highest point of the reactor. HUASB reactor has a few focal points over UASB reactor, for example,

Higher effectiveness in the treatment of an assortment of waste waters including high quality waste water at high OLR and lesser HRT

Expanded maintenance of granular slop and counteractive action of washout of microbial populace and so on.

The UASB procedure comprises of an Upflow of wastewater through a thick ooze bed with high microbial movement. In the reactor, the solids profile shifts from exceptionally thick and granular particles with great settling ability near the base (slop bed), to increasingly scattered and light slime particles near the top (muck cover). The UASB reactor can be partitioned into four segments: the ooze bed, the ooze cover, the gas-solids-fluid separator (for example 3-stage separator) and the optional settling compartment over the separator.

The slop bed is arranged in the base of the reactor and comprises of a thick slime with excellent settling attributes; it is in this way kept in the reactor. Over the muck bed is the slop cover, with solids introducing lower fixations and settling speeds. The slime cover comprises of ooze particles in a blend with the biogas framed, and is in this way held in suspension. It is in these two compartments, the slop bed and the slime cover, that the approaching wastewater is naturally corrupted.

\section{Materials and Methods}

The wastewater was gathered from a Pharma Industry Named MegafinePharma, Vapi, Gujarat, India (Table 1). The business is it's sort of in India for the assembling of pharma based items and pharma intermediates.

The reactor was inoculated with dynamic biomass got from the anaerobic digester of Emami Healthcare Ltd., Vapi, Gujarat, which is in task in the current treatment offices situated at the business ETP. A little amount of jiggery was added to the reactor with water as supplement. The clarified set-up comprised of cross breed UASB reactor, made of a PVC material with a round and hollow segment of 152.4 inner distance across; $1210 \mathrm{~mm}$ stature absolute volume of $0.021 \mathrm{~m} 3$; powerful volume of $0.018 \mathrm{~m} 3$. The chose pressing material was situated at the best $33 \%$ of the reactor. The reactors were sustained from the influent tank through PVC tube by methods for a gravitational stream. A metal check valve of $25 \mathrm{~mm}$ size was fixed at the base of the reactor to encourage the ooze withdrawal. Five inspecting ports were introduced along the tallness of the reactor at various zones viz., muck bed zone, sludge cover zone and settling zone. The influent tank was given of 20 liters. This outlet was associated through a silicon cylinder to a wet gas meter.

In this study, locally available PVC support media is used. The PVC spiral packing media comprises of numerous windings (or) Sshaped portions.

\section{Characteristic of the waste water}

\section{Characterization of microorganisms}

\section{Culturing anaerobes}

Microscopic organisms will just develop in a domain that contains a suitable convergence 
of oxygen. For instance, commit aerobes become just within the sight of oxygen, though commit anaerobes become just in a sans oxygen condition. Refined of microorganisms hence requires development under an air that underpins their development (Table 2).

Anaerobic container

Shake culture technique.

Chemical reducing agents.

\section{Start Up}

The primary target to be accomplished in the start-up of any high rate anaerobic reactor is to achieve a palatable and predictable immobilization of anaerobic creatures. Startup routine of the above reactor can be considered as the second compelling piece of the constant method of activity, the first being the acclimatization in the cluster method of activity. A generally low volumetric stacking rate is prescribed for the essential start-up of HUASB reactor.

The HUASB reactor was seeded from acclimatized seed ooze got from the bunch mode activity. At first around 30-40\% of the reactor volume was topped off with dynamic muck.

\section{Results and Discussion}

\section{Microbial analysis}

From the laboratory analysis of the sludge of the reactor using standard analytical techniques the low volume sample has negative result and all other are in positive (Table 4 and 5).

\section{pH}

$\mathrm{pH}$ values gently increase with decrease in time of operation and found to be in the range of 7.89- 6.7 is shown in graph 3-5.

\section{Alkalinity}

Alkalinity concentration is decreases with time in $1^{\text {st }} \& 2^{\text {nd }}$ recycling but there is variation in continuous flow system. The values are in range of 11519-35008.5 which is shown in the graphs given below.

\section{TSS and VSS}

Suspended solid concentration is increasing absolutely with time period because of biomass activity. The value of TSS and VSS of effluent is $300 \mathrm{mg} / \mathrm{L}$ and $362 \mathrm{mg} / \mathrm{L}$ which is increased to $5355 \mathrm{mg} / \mathrm{L}$ and $4444 \mathrm{mg} / \mathrm{L}$ at maximum reduction

\section{COD removal}

COD removal percentage also increases with time of operation and is in the range of 6.18 $\%$ to $71.99 \%$ and the maximum efficiency of $71.99 \%$ is obtained which can be expressed in graphs as given below.

In conclusion, anaerobic debasement of the pharmaceutical business squander water is completed in the half breed UASB reactor. Based on the outcomes we can reason that the UASB reactor and the adjustment done in the reactor can be utilized for the pharmaceutical business squander water. Here the reactor additionally delivers adequate measure of the methane gas which can be utilized as fuel, which is potential wellspring of the vitality. It likewise gives high productivity for the reactor so it tends to be utilized for the treatment.

The greatest COD evacuation effectiveness is $71.99 \%$ with normal profluent COD fixation as $62000 \mathrm{mg} / \mathrm{l}$. The normal BOD evacuation effectiveness in first and second reusing framework it is $37.23 \%$. What's more, it is 71.9\% most extreme in both constant frameworks (Table 5a-5c). 
Table.1 Wastewater generation in pharma industry

\begin{tabular}{|c|l|l|l|}
\hline $\begin{array}{c}\text { Sr. } \\
\text { No }\end{array}$ & $\begin{array}{l}\text { Source of wastewater } \\
\text { Generation }\end{array}$ & $\begin{array}{l}\text { Range of average characteristics } \\
\text { except } \mathbf{p H}\end{array}$ & Effluent in mg/I \\
\hline $\mathbf{1}$ & Sterile products & $\begin{array}{l}\text { BOD } \\
\text { TSS }\end{array}$ & $\begin{array}{l}50 \text { to } 100 \\
20 \text { to } 260\end{array}$ \\
\hline $\mathbf{2}$ & Syrup preparation & $\begin{array}{l}\text { COD } \\
\text { Cl- }\end{array}$ & $\begin{array}{l}150 \text { to } 2500 \\
20 \text { to } 150\end{array}$ \\
\hline $\mathbf{3}$ & Malt preparation & $\begin{array}{l}\text { BOD } \\
\text { So4- }\end{array}$ & $\begin{array}{l}300 \text { to } 2,000 \\
20 \text { to } 200\end{array}$ \\
\hline $\mathbf{4}$ & Pastilles preparation & $\begin{array}{l}\text { BOD } \\
\text { Heavy metals } \\
\text { TSS } \\
\text { pH }\end{array}$ & $\begin{array}{l}2,000 \text { to } 2,500 \\
1 \text { to } 20 \\
100 \text { to } 300 \\
\text { to } 8.0\end{array}$ \\
\hline
\end{tabular}

Table.2 Dimensions of the lab scale rector

\begin{tabular}{|c|l|c|}
\hline \multicolumn{2}{|c|}{ Physical Parameter } & Size \\
\hline \multirow{2}{*}{ Height } & Total Height & $1210 \mathrm{~mm}$ \\
\cline { 2 - 3 } & Effective Height & $1020 \mathrm{~mm}$ \\
\cline { 2 - 3 } & Packing Material Height & $90 \mathrm{~mm}$ \\
\hline \multirow{2}{*}{ Diameter } & Inner Diameter & $152.4 \mathrm{~mm}$ \\
\cline { 2 - 3 } & Outer Diameter & $153.1 \mathrm{~mm}$ \\
\hline \multirow{2}{*}{ Volume } & Total Volume & $0.021 \mathrm{~m}^{3}$ \\
\cline { 2 - 3 } & Effective Volume & $0.018 \mathrm{~m}^{3}$ \\
\hline \multirow{2}{*}{$\begin{array}{c}\text { Sampling } \\
\text { port }\end{array}$} & 1- Sludge Bed Zone & $200 \mathrm{~mm}$ \\
\cline { 2 - 3 } $\begin{array}{c}\text { Height } \\
\text { (From }\end{array}$ & 2-Sludge Blanket Zone & $380 \mathrm{~mm}$ \\
\cline { 2 - 3 } Base) & 3- Sludge Blanket Zone & $560 \mathrm{~mm}$ \\
\cline { 2 - 3 } & 4- Settling Zone & $740 \mathrm{~mm}$ \\
\cline { 2 - 3 } & 5- Settling Zone & $920 \mathrm{~mm}$ \\
\hline
\end{tabular}

Table.3 Characteristic of water

\begin{tabular}{|l|c|}
\hline Parameter (mg/L) & Result \\
\hline pH & 11.55 \\
\hline Ammonical Nitrogen & 138.5 \\
\hline BOD & 18328 \\
\hline COD & 54821.4 \\
\hline Chloride as Cl & - \\
\hline Oil \& Grease & 488.9 \\
\hline Phenolic Compound & 8.1 \\
\hline Sulphate SO4- & 1.4 \\
\hline Alkalinity as Methyl Orange & 70 \\
\hline Total Dissolved Solid & 33312.5 \\
\hline Total Suspended Solid & 1992 \\
\hline
\end{tabular}


Table.4 Result growth of Microorganism

\begin{tabular}{|c|c|c|c|}
\hline Batch No & Source of Culture & Type of medium & Result \\
\hline \multirow[t]{3}{*}{ 1st Batch } & \multirow[t]{3}{*}{ Supernatant of Emami sludge } & N-Broth & - ve \\
\hline & & N-Broth & + ve \\
\hline & & N-Broth & $+\mathrm{ve}$ \\
\hline \multirow[t]{2}{*}{ 2nd Batch } & \multirow[t]{2}{*}{ From 1st Batch } & N-Broth & $+\mathrm{ve}$ \\
\hline & & N-Broth & + ve \\
\hline \multirow[t]{7}{*}{ 3rd Batch } & \multirow[t]{3}{*}{ From 1st Batch } & $\mathrm{N}$ - Agar slant & - ve \\
\hline & & $\mathrm{N}$ - Agar slant & + ve \\
\hline & & $\mathrm{N}$ - Agar slant & + ve \\
\hline & \multirow[t]{3}{*}{ From 2nd Batch } & $\mathrm{N}$ - Agar slant & + ve \\
\hline & & $\mathrm{N}$ - Agar slant & - ve \\
\hline & & $\mathrm{N}$ - Agar slant & + ve \\
\hline & From 1st Batch & $\mathrm{N}$ - Agar Plate & $+\mathrm{ve}$ \\
\hline
\end{tabular}

Table.5a Result of 1st and 2nd recycle

\begin{tabular}{|c|c|c|c|c|c|}
\hline COD mg/L & \% Removal & BOD mg/L & pH & TSS mg/l & Gas m3/d \\
\hline $\mathbf{5 7 6 1 2}$ & 6.18 & 19780 & 7.89 & 362 & 0.002 \\
\hline $\mathbf{4 7 1 1 2}$ & 23.28 & 15590 & 7.78 & 1789 & 0.008 \\
\hline $\mathbf{3 9 3 2 4 . 2}$ & 35.96 & 13275.2 & 7.56 & 2764 & 0.012 \\
\hline $\mathbf{3 1 7 3 9}$ & 48.31 & 10601.4 & 7.65 & 3713 & 0.017 \\
\hline $\mathbf{2 6 5 8 5 . 6}$ & 56.70 & 9050 & 7.33 & 4358 & 0.019 \\
\hline $\mathbf{5 6 0 6 0}$ & 8.70 & 19132 & 7.85 & 669 & 0.003 \\
\hline $\mathbf{4 6 8 7 4 . 6}$ & 23.66 & 15905 & 7.69 & 1819 & 0.008 \\
\hline $\mathbf{3 7 3 2 8}$ & 39.21 & 12785 & 7.55 & 3014 & 0.013 \\
\hline $\mathbf{2 5 2 1 0 . 8}$ & 58.94 & 8615.2 & 7.23 & 4530 & 0.020 \\
\hline $\mathbf{2 0 4 9 6}$ & 66.62 & 6985.7 & 6.98 & 5120 & 0.023 \\
\hline
\end{tabular}

Table 5b Result of $1^{\text {st }}$ Continuous System

\begin{tabular}{|c|c|c|c|c|c|}
\hline $\begin{array}{c}\text { COD } \\
\text { mg/L }\end{array}$ & $\begin{array}{c}\text { \% } \\
\text { Removal }\end{array}$ & $\begin{array}{c}\text { BOD } \\
\text { mg/L }\end{array}$ & pH & $\begin{array}{c}\text { TSS } \\
\mathbf{m g} / \mathbf{l}\end{array}$ & $\begin{array}{c}\text { Gas } \\
\mathbf{m 3 / d}\end{array}$ \\
\hline $\mathbf{2 1 5 7 8}$ & 64.86 & 7375.8 & 7.12 & 4985 & 0.022 \\
\hline $\mathbf{2 1 4 5 6}$ & 65.06 & 7305.09 & 7.45 & 5000 & 0.022 \\
\hline $\mathbf{2 2 6 4 5}$ & 63.12 & 7785.92 & 7.3 & 4851 & 0.022 \\
\hline $\mathbf{2 1 8 1 5 . 3}$ & 64.47 & 7400 & 7.01 & 4955 & 0.022 \\
\hline $\mathbf{2 0 4 7 6 . 2}$ & 66.65 & 6905 & 6.98 & 5123 & 0.023 \\
\hline $\mathbf{2 0 1 1 2}$ & 67.25 & 6875 & 7.2 & 5168 & 0.023 \\
\hline $\mathbf{1 9 5 4 8 . 2}$ & 68.17 & 6649 & 7.15 & 5239 & 0.023 \\
\hline $\mathbf{2 0 1 4 5 . 5}$ & 67.19 & 6875.17 & 7.03 & 5164 & 0.023 \\
\hline $\mathbf{1 8 4 7 8}$ & 69.91 & 6208 & 7.08 & 5373 & 0.024 \\
\hline $\mathbf{1 8 5 4 1 . 1}$ & 69.81 & 6310.8 & 7.06 & 5365 & 0.024 \\
\hline
\end{tabular}


Table.5c Result of $1^{\text {st }}$ Continuous System

\begin{tabular}{|c|c|c|c|c|c|}
\hline COD mg/L & \% Removal & BOD mg/L & $\mathbf{p H}$ & $\begin{array}{c}\text { TSS } \\
\mathbf{m g} / \mathbf{l}\end{array}$ & $\begin{array}{c}\text { Gas } \\
\mathbf{m 3 / d}\end{array}$ \\
\hline $\mathbf{1 8 5 9 5}$ & 69.72 & 6330 & 6.99 & 5358 & 0.024 \\
\hline $\mathbf{1 7 9 9 5}$ & 70.69 & 3125 & 6.85 & 5433 & 0.024 \\
\hline $\mathbf{1 7 5 8 5 . 3}$ & 71.36 & 5975 & 6.82 & 5485 & 0.025 \\
\hline $\mathbf{1 8 5 6 6}$ & 69.76 & 6330 & 6.78 & 5362 & 0.024 \\
\hline $\mathbf{1 8 7 8 3 . 3}$ & 69.41 & 6380 & 6.66 & 5335 & 0.024 \\
\hline $\mathbf{1 9 2 2 5}$ & 68.69 & 6542 & 6.72 & 5279 & 0.024 \\
\hline $\mathbf{1 8 1 2 4 . 2}$ & 70.48 & 6158 & 6.8 & 5417 & 0.024 \\
\hline $\mathbf{1 8 5 3 5}$ & 69.82 & 6305.7 & 6.75 & 5366 & 0.024 \\
\hline $\mathbf{1 8 8 2 5 . 2}$ & 69.34 & 64010 & 6.7 & 5330 & 0.024 \\
\hline $\mathbf{1 8 9 5 6 . 6}$ & 69.13 & 6420 & 6.72 & 5313 & 0.024 \\
\hline
\end{tabular}

Fig.1\&2 UASB reactor \& The sketch of lab scale hybrid UASB Reactor
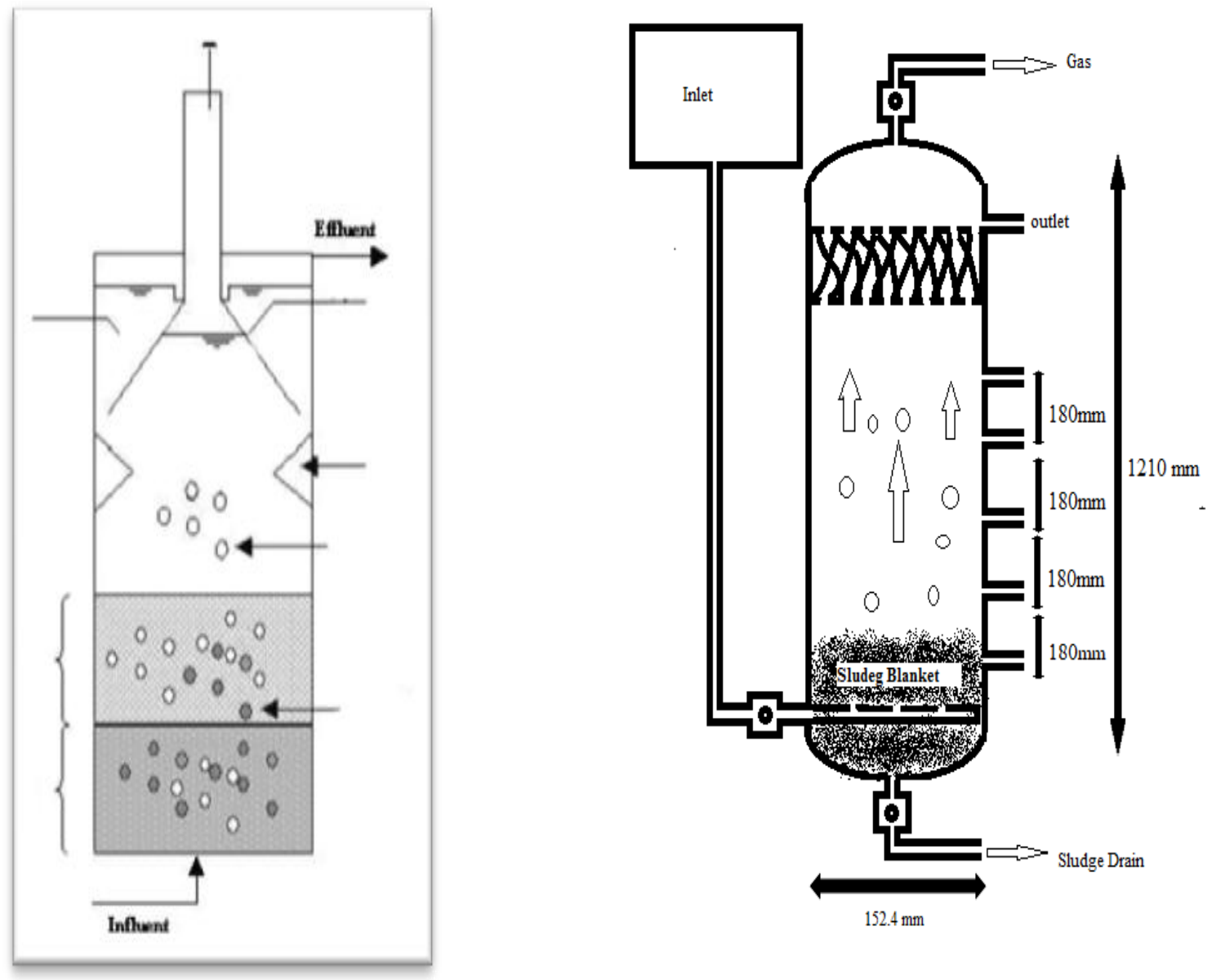

$152.4 \mathrm{~mm}$ 
Fig.3\&4 Reduction of COD in 1st\& 2nd recycle \& Reduction of COD in 1st Continuous system
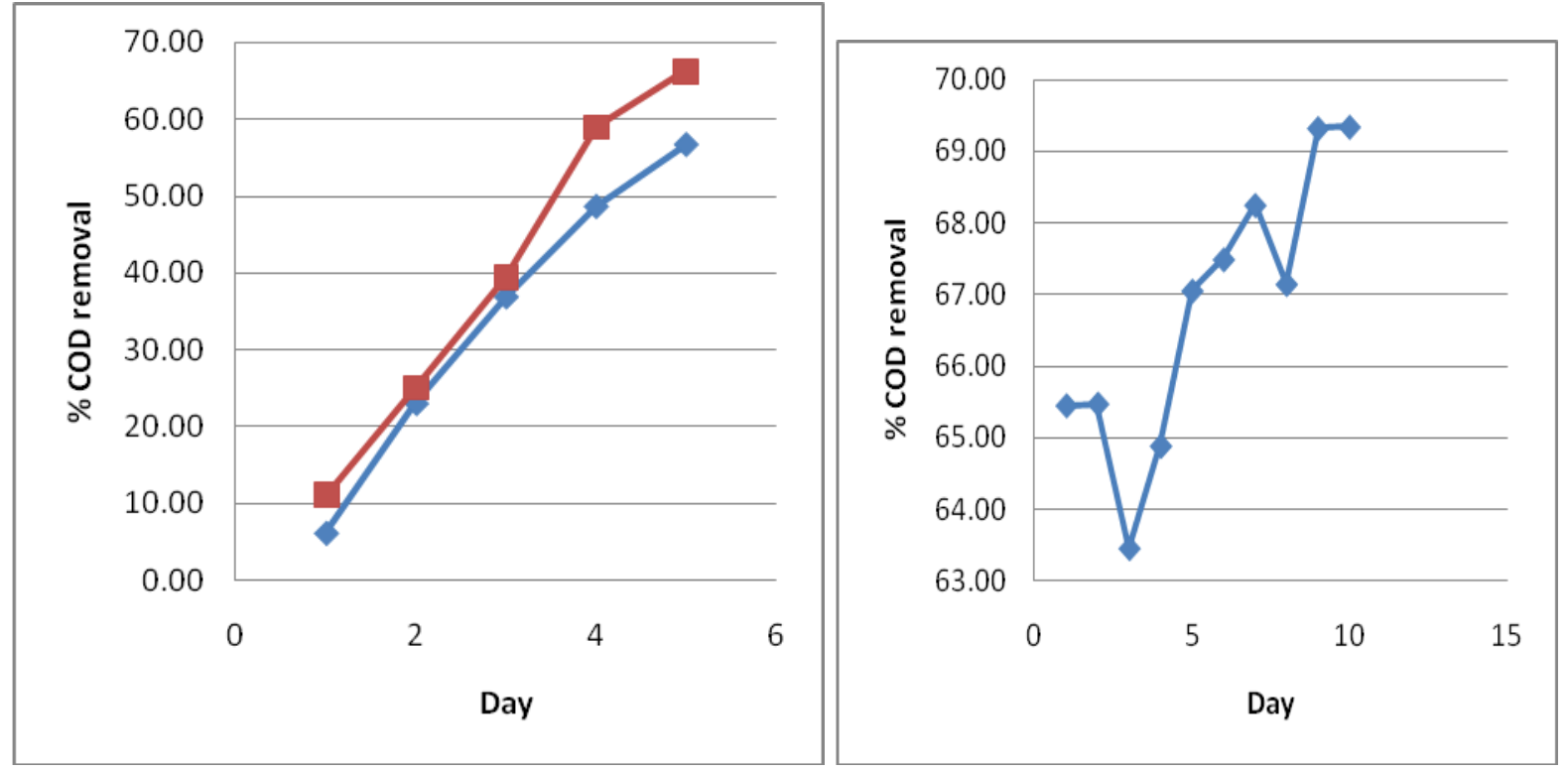

Fig.5 Reduction of COD in 2nd Continuous system

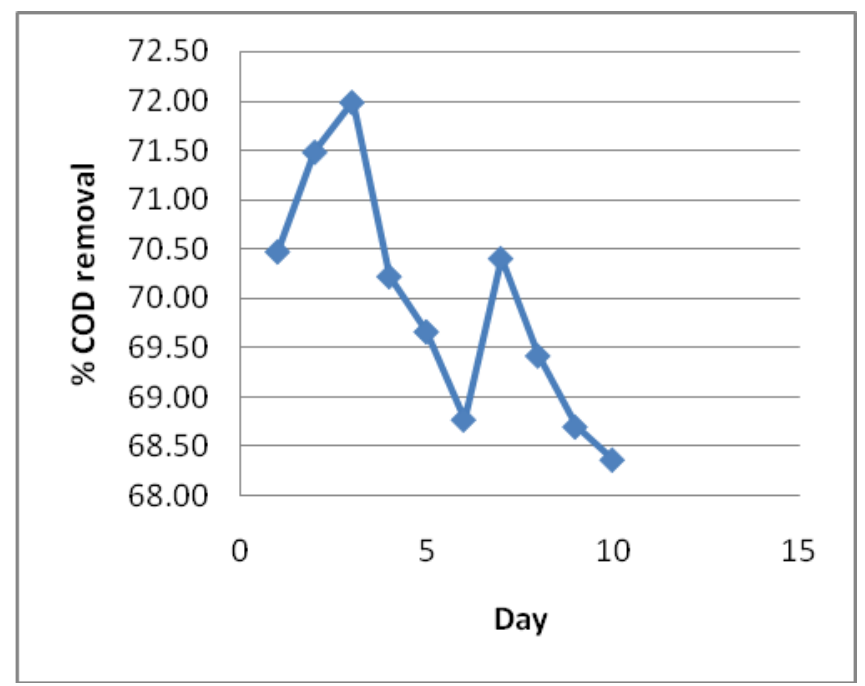

It is diminished most extreme to $5975 \mathrm{mg} / \mathrm{L}$ from normal in familiar BOD $19000 \mathrm{mg} / \mathrm{L}$. Alkalinity of the emanating water is diminished to $35000 \mathrm{mg} / \mathrm{l}$ normal to 10935 at greatest. Here TSS and VSS is expanding from $300 \mathrm{mg} / \mathrm{L}$ and $362 \mathrm{mg} / \mathrm{L}$ to $5355 \mathrm{mg} / \mathrm{L}$ and $4444 \mathrm{mg} / \mathrm{L}$ at greatest dimension. The underlying $\mathrm{pH}$ of the influent was normal 8.5, and the last gushing $\mathrm{pH}$ was diminished to
6.9. There was a truly ideal difference in the $\mathrm{pH}$ after the organic response.

\section{Acknowledgement}

I would like thank Dr.DipakVyas, my guide and PG coordinator of our college. I am thankful to Dr. F.S Umrigar, our principal and Dr. L.B. Zala Head of Civil Engineering 
Department. I am also thankful to Mrs Sejal Patel and Unistar Environmental consultancy for providing me laboratory facility.

\section{References}

Anushuya R and Rao YS, "Comparative performance of UASB and anaerobic hybrid reactors for the treatment of complex phenolic wastewater" Bioresource Technology 123, 352-35, 2012.

Bhunia $\mathrm{P}$ and Ghangrekar MM, "Analysis, evaluation, and optimization of kinetic parameters for performance appraisal and design of UASB reactors", Bioresource Technology, 2132-2140, 2008.

Banu JR and Anandan S, "Treatment of dairy wastewater using anaerobic and solar photocatalytic methods", Solar Energy 82, 812-819. 2008.

C.P.C.B. "Minimal national standards Pharmaceutical manufacturing and formulation industry"1, pg. no 9, 13, 20, 28, 29, Comprehensive industry document series /1988-89

Cordoba PR and Alejandro P, "Improved Performance of a Hybrid Design Over an Anaerobic Filter for the Treatment of Dairy Industry Wastewater at Laboratory Scale", Journal of fermentation and bioengineering, Vol. 79, No. 3, 270-212. 1995

Dilek E and Ozturk I, "System Performance in UASB Reactors Receiving Increasing Levels of Sulfate", Clean 2007, 35 (3), 275-28, 2007

Farajzadehha S and Mirbagheri SA, "Lab Scale Study of HRT and OLR Optimization in UASB Reactor for Pretreating Fortified Wastewater in Various Operational Temperatures", APCBEE Procedia 1, 90 - 95, 2012.

Gualtero S M, "Pollution Prevention Measures for Unwanted
Pharmaceuticals", Department of Earth and Environmental Engineering Columbia University, 2005.

Gupta SK, "Morphological study of the granules in UASB and hybrid reactors", Clean Techn Environ Policy, 203-212 DOI 10.1007, 2005

Haandel AV and Kato MT, "Anaerobic reactor design concepts for the treatment of domestic wastewater", "Environmental Science and Bio/Technology, DOI 10.1007/s11157005-4888,2006.

HutnÏan $M$ and Drtil $M$, "Comparison of startup and anaerobic wastewater treatment in UASB, hybrid and baffled reactor", Bioprocess Engineering 21 (1999) 439 \pm 445 Ó Springer-Verlag 1999

Kassam ZA and Yerushalmi L, "A market study on the anaerobic wastewater Treatment systems", Water, Air, and Soil Pollution, 179-192, Kluwer Academic Publishers, 2003.

Lepisto S S and Rintala J A, "Start-up and Operation of Laboratory-Scale Thermophilic Upflow Anaerobic Sludge Blanket Treating Vegetable Processing wastewaters", J. Chem. Tech. Biotechnol. 1997.

Luostarinen SA and Rintala JA, "Anaerobic on-site treatment of black water and dairy parlour wastewater in UASBseptic tanks at low temperatures", Water Research 39, 436-448, 2005.

MondalPk and Usmani QS, "Anaerobic biodegradation of triphenylmethane dyes in a hybrid UASFB reactor for wastewater remediation", Springer Science Business Media, Biodegradation, DOI 10.1007/s10532010-9364, 2010.

Omil F and Garrido JM, "Anaerobic filter reactor performance for the treatment of complex dairy wastewater at industrial scale", Water Research 37, 4099-4108, 
2003

Qiu G and Song Y, "Combination of upflow anaerobic sludge blanket (UASB) and membrane bioreactor (MBR) for berberine reduction from wastewater and the effects of berberine on bacterial community dynamics" Journal of Hazardous Material246-247, 34-43, 2013.

Ren TT and Yu HU, "Hydrodynamics of Upflow Anaerobic Sludge Blanket Reactors", Wiley InterScience, DOI 10.1002/aic, 2008.

Seghezzo L and Trupiano AP, "Two-Step Upflow Anaerobic Sludge Bed System for Sewage Treatment Under Subtropical Conditions with Post treatment in Waste Stabilization Ponds", Humana Press Inc. 02732289/03/109/0167, 2003

Selvamurugan $\mathrm{M}$ and Valliappan $\mathrm{K}$, "Performance evaluation of full-scale upflow anaerobic sludge blanket reactor treating distillery spentwash", Clean Techn Environ Policy, DOI 10.1007/s10098-011-0396-7, SpringerVerlag 2011.

Senthil MK and Gnanapragasam G, "Influence of hydraulic retention time in a two-phase upflow anaerobic sludge blanket reactor treating textile dyeing effluent using sago effluent as the cosubstrate", Environ SciPollut Res, 649654 DOI 10.1007/s11356-010-04099.2006 .

Tare V and Nema A, "UASB Technology Expectation and Reality", Foundation of Greentech Environment System, New Delhi, 2002.

Uldal M, "Effect of Hydraulic Loading Variation on a Pilot Scale UASB Reactor Treating Domestic Wastewater at Vapi CETP, India", Water and Environmental Engineering, Indian Institute of Technology, Kanpur. 2008

Yaobin Z and Xie Q, "Performance of a ZVIUASB reactor for azo dye wastewater treatment", Wiley online library DOI 10.1002/jctb.248, 2010.

\section{How to cite this article:}

Ritvij D. Trivedi, Dipak S. Vyas and Sejal M. Patel. 2019. Hybrid UASB Reactor: A Research Evaluation for Treatment of Pharmaceutical Industry Wastewater. Int.J.Curr.Microbiol.App.Sci. 8(04): 1453-1461. doi: https://doi.org/10.20546/ijcmas.2019.804.170 